\title{
Postdural Puncture Headache in Multiple Sclerosis; What Shall We Do Now? Case Report
}

\author{
Multiple Sklerozda Postdural Baş Ağrısı, \\ Şimdi Ne Yapacağız? Olgu Sunumu
}

\begin{abstract}
Potential effects of epidural pressure changes caused by epidural blood patch applications are important due to their interference with axonal conduction in patients with multiple sclerosis. There are limited number of case reports about safety and efficiency of epidural blood patch applications in multiple sclerosis patients. Herein, we aimed to report a successful epidural blood patch treatment in a 26-year-old female patient with multiple sclerosis.
\end{abstract}

Keywords: Multiple sclerosis, postdural puncture headache, blood patch epidural

öz

Multipl sklerozlu hastalarda epidural kan yaması uygulamalarının oluşturduğu basınç değişikliklerinin akson iletimi üzerine olası etkileri önemlidir. Multiple sklerozlu hastalarda epidural kan yamasının güvenliği ve etkinliğine dair kısıtlı sayıda olgu sunumu vardır. Biz burada, 26 yaşında multiple sklerozlu kadın hastada postdural ponksiyon baş ağrısının başarılı tedavisini anlatmayı amaçladık.

Anahtar kelimeler: Multiple skleroz, postdural baş ağrısı, epidural kan yaması
Alındığı tarih: 26.08 .2019

Kabul tarihi: 10.09 .2019

Yayın tarihi: 31.10 .2019

Atıf vermek için: Cavus Z, Coskun N. Postdural puncture headache in multiple sclerosis; what shall we do now?. JARSS 2019;27(4):308-10.

Zuhal Cavus
Özel Duygu Hastanesi
zaziosmanpaşa - İstanbul - Türkiye
ORCiD: 0000-0002-7588-5240
N. Coskun 0000-0001-7097-3519
Şehit Prof. Dr. Ilhan Varank Sancaktepe
Eğitim ve Araştirma Hastanesi,
Istanbul, Türkiye

\section{INTRODUCTION}

Multiple sclerosis is characterized with demyelination, axonal injury and sclerotic plaques in the white matter of the central nervous system. Diagnosis of multiple sclerosis (MS) depend on clinical suspicion and the findings of magnetic resonance imaging but cerebrospinal fluid (CSF) analysis is still mandatory. CSF analysis has most typically revealed the presence of oligoclonal bands, mild pleocytosis and increased protein levels.

August Bier described the first case of postdural puncture headache (PDPH) in 1898. The overall incidence of PDPH varies in different studies and in different patient groups, while the peak incidence of $36 \%$ is reported after diagnostic lumbar puncture ${ }^{(1)}$. Epidural blood patch (EBP) is the most effective choice (61-98\%) for treatment when conservative management is failed (2).
EBP in multiple sclerosis patients is a concern because of the potential risk of interference with axonal conduction due to changes in epidural space pressure. There are limited number of case reports about safety and efficiency of EBP in multiple sclerosis patients. Herein, we aimed to report a successful treatment of PDPH with EBP in a female multiple sclerosis patient.

\section{CASE REPORT}

A 26-year-old female patient had symptoms of numbness, tingling in lower extremities, fatigue, mobility problems, muscle spasms, stiffness and weakness for 15 days. Physical examination was normal except exaggerated deep tendon reflexes. Magnetic resonance imaging (MRI) revealed multiple hyperintense lesions in left occipital and temporal white matter regions in T2-flair sections (Figure 1). She was diagnosed as multiple sclerosis according to 


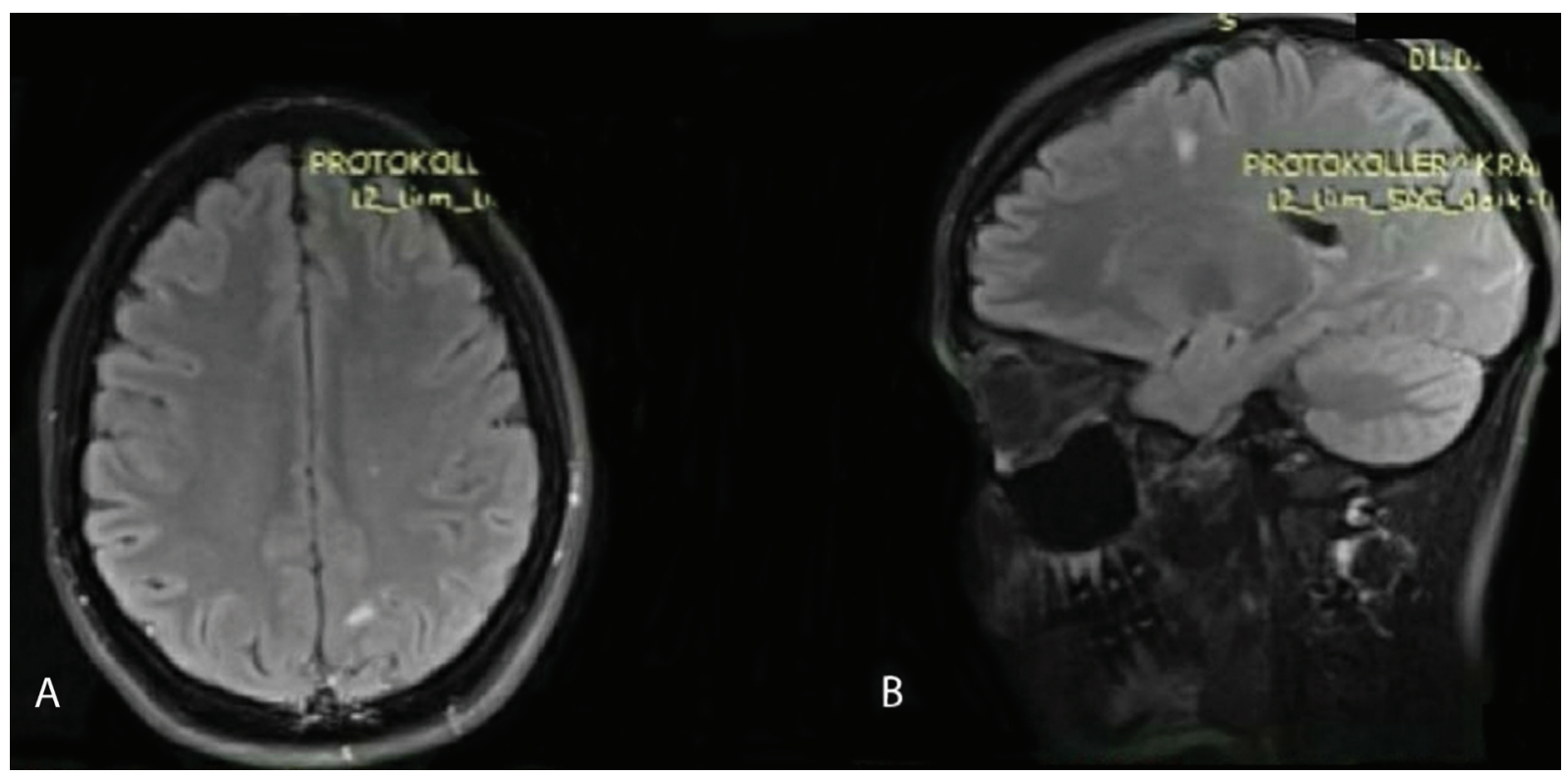

Figure 1. A-Hyperintense lesion in occipital area in T2 flair section, B-Hyperintense lesions in occipital and parietal area in $\mathrm{T} 2$ flair section

clinical and radiological evaluations. Lumbar punction was planned to confirm the diagnosis and rule out clinical conditions including infectious and noninfectious inflammatory disorders.

Lumbar punction was achieved at first attempt with a 25 gauge Quincke spinal needle inserted between L4-5 vertebras under sterile conditions. Cerebrospinal fluid examination results for IgG, albumin and oligoclonal bands confirmed the diagnosis of multiple sclerosis. The patient was hospitalised and treatment for MS was started. The day after lumbar punction she had severe headache especially localized on the occipital region of head. Headache, neck stiffness with nausea and vomiting were getting worse on ambulation. Conservative treatment including bed rest, intravenous hydration, caffeine supplementation and analgesic medication was started. Despite conservative treatment symptoms were worsened, her daily life activities were restricted. EBP recommended to the patient by explaining its risks and consequences. A detailed informed consent was taken before the procedure.

EBP was performed at the fourth day of lumbar punction with the patient in the right lateral position using $19 \mathrm{~mL}$ blood drawn from the left antecubital vein. She had an instant relief even during the procedure. The patient lied still for $1-2 \mathrm{~h}$ in a supine position and is then mobilized. There was no change in neurological symptoms and radiological findings on repeated MRI scans performed during the follow- up period. She was discharged without any symptoms and findings except mild back pain. Patient was warned to stay away from straining after the procedure which might lessen the risk of dislodgement of the blood clot.

\section{DISCUSSION}

PDPH is a main obstacle of neuraxial interventions and the impending risks factors have been reported to be female gender, young adults, multiple dural punctures, the size/type and orientation of the needle, previous history, midline lumbar puncture approach, type of local anesthetic solution, and experience of the clinician ${ }^{(2)}$.

Projected mechanisms for etiology of PDPH include diminished CSF production, hyperabsorption of CSF and CSF leakage through small meningeal lacerations and related intracranial hypotension. PDPH typically expressed as a severe and primarily frontooccipital pain which is irritating in the standing position. Nausea, vomiting, and visual/auditory disturbances might be observed. The PDPH onsets between 24 to 72 hours after epidural puncture, and symptoms persist up to two weeks as generally reported in the literature ${ }^{(3)}$. 
Conventional treatment strategy consists of bed rest in supine position, rehydration, use of simple analgesics, caffeine supplements, opioids and anti-emetics and more than $85 \%$ of headaches will resolve without any specific treatment ${ }^{(1)}$.

If PDPH prolongs more than one week, then after eliminating other diagnoses including meningitis, migraine, tension or cluster headache, cerebral angiopathy, subarachnoid hemorrhage, cortical vein thrombosis, space occupying lesion and caffeine withdrawal syndrome, treatment with EBP might be considered. Contraindications for this procedure are the presence of fever, local infection in the back and bleeding disorders.

The mechanism of an epidural blood patch in the treatment of PDPH still remains unclear. Various theories are suggested including plug theory in which formation of plug after EBP might seal the dural hole and decrease CSF leak and pressure patch theory which was based on elevation of epidural pressure with injection that increases subarachnoid CSF pressure by compressing the dura ${ }^{(4)}$.

Authors postulated that main concern in EBP application in MS patients is elevated pressure in the epidural space that might affect nervous conduction in the vulnerable components of the central nervous system which are already affected in MS. During the EBP procedure injected blood volume compresses neurological tissue with a mass effect. Injected blood volume determines changes in the epidural pressure. The pressure can be minimized by slowing down the speed of injection. The number of case reports about performing EBP in MS patients is very limited. Koeva et al. ${ }^{(5)}$ reported a successful EBP treatment in a 50-year-old-female MS patient with PDPH. They used evoked responses to evaluate the effects of EBP on axonal conduction and reported a small increase in evoked P40 response latency which is not significant. Kovacs et al. ${ }^{(6)}$ suggested that EBP can be applicable in MS patients without any precaution if the injection is made slowly.
Despite a consensus indicating that neuroaxial anesthesia is a risk for patients with MS; literature about EBP in this type of patients is limited and main concern seems to be the possibility of neurological deficit due to increased epidural pressure after EBP. In order to avoid elevation of epidural pressure the speed and volume of injection are the key factors. In this case report we performed EBP under vigilant clinical follow up in a young female MS patient without any complications.

Çıkar Çatışması: Yoktur

Finansal Destek: Yoktur

Hasta Onamı: Olgudan yazılı onam alınmıştır.

Conflict of Interest: None

Funding: None

Informed Consent: Written informed consent form was obtained from the patient.

\section{REFERENCES}

1. Ahmed SV, Jayawarna C, Jude E. Post lumbar puncture headache: diagnosis and management. Postgrad Med J. 2006;82:713-6. https://doi.org/10.1136/pgmj.2006.044792

2. Kwak KH. Postdural puncture headache. Korean J Anesthesiol. 2017;70:136-43. https://doi.org/10.4097/kjae.2017.70.2.136

3. Porhomayon J, Zadeii G, Yarahamadi A, Nader ND. A case of prolonged delayed postdural puncture headache in a patient with multiple sclerosis exacerbated by air travel. Case Rep Anesthesiol. 2013;2013:253218. https://doi.org/10.1155/2013/253218

4. Kim J, Lee S, Ko Y, Lee W. Treatment with epidural blood patch for iatrogenic intracranial hypotension after spine surgery. J Korean Neurosurg Soc. 2012;52:254-6. https://doi.org/10.3340/jkns.2012.52.3.254

5. Koeva V, Bar-Or A, Gendron D, Backman SB. Epidural blood patch in a patient with multiple sclerosis: is it safe? Can J Anaesth. 2013;60:479-83. https://doi.org/10.1007/s12630-013-9904-z

6. Kovacs M, Ravindran M. Epidural blood patch for postdural puncture headache in a parturient with multiple sclerosis. Euroanesthesia 2017. 